\title{
Article
}

\section{Conjugative Plasmids Disseminating CTX-M-15 among Human, Animals and the Environment in Mwanza Tanzania: A Need to Intensify One Health Approach}

\author{
Caroline A. Minja ${ }^{1, *}$, Gabriel Shirima ${ }^{1}$ and Stephen E. Mshana ${ }^{2}$ (I) \\ 1 School of Life Sciences, Department of Global Health and Biomedical Sciences, \\ Nelson Mandela African Institution of Science and Technology, Arusha 23306, Tanzania; \\ gabriel.shirima@nm-aist.ac.tz \\ 2 Department of Microbiology and Immunology, Catholic University of Health and Allied Sciences, \\ Mwanza 33109, Tanzania; mshana72@bugando.ac.tz \\ * Correspondence: minjac@nm-aist.ac.tz
}

check for updates

Citation: Minja, C.A.; Shirima, G.; Mshana, S.E. Conjugative Plasmids Disseminating CTX-M-15 among

Human, Animals and the

Environment in Mwanza Tanzania: A Need to Intensify One Health Approach. Antibiotics 2021, 10, 836. https://doi.org/10.3390/

antibiotics 10070836

Academic Editor: João Botelho

Received: 2 May 2021

Accepted: 30 June 2021

Published: 9 July 2021

Publisher's Note: MDPI stays neutral with regard to jurisdictional claims in published maps and institutional affiliations.

Copyright: (C) 2021 by the authors. Licensee MDPI, Basel, Switzerland. This article is an open access article distributed under the terms and conditions of the Creative Commons Attribution (CC BY) license (https:/ / creativecommons.org/licenses/by/ $4.0 /)$.

\begin{abstract}
Background: Globally, bla $_{\mathrm{CTX}-\mathrm{M}-15}$ beta-lactamases are the most popular extended spectrum beta-lactamase alleles that are widely distributed due its mobilisation by mobile genetic elements in several compartments. We aimed to determine the conjugation frequencies and replicon types associated with plasmids carrying $b l a_{\mathrm{CTX}-\mathrm{M}-15}$ gene from Extended Spectrum Beta-lactamase producing isolates in order to understand the dissemination of resistance genes in different compartments. Material and methods: A total of 51 archived isolates carrying bla $a_{\mathrm{CTX}-\mathrm{M}-15}$ beta-lactamases were used as donors in this study. Antibiotic susceptibility tests were performed as previously described for both donors and transconjugants. Conjugation experiment was performed by a modified protocol of the plate mating experiment, and plasmid replicon types were screened among donor and transconjugant isolates by multiplex Polymerase Chain Reaction in a set of three primer panels. Results: The conjugation efficiency of plasmids carrying bla $a_{\mathrm{CTX}-\mathrm{M}-15}$ was $88.2 \%$ (45/51) with conjugation frequencies in the order of $10^{-1}$ to $10^{-9}$ and a $100 \%$ transfer efficiency observed among E. coli of animal origin. Majority of donors $(n=21)$ and transconjugants $(n=14)$ plasmids were typed as either Inc FIA or Inc FIB. Resistance to non-beta-lactam antibiotics was transferrable in 34/45 (75.6\%) of events. Ciprofloxacin, tetracycline and sulphamethoxazole-trimethoprim resistance was co-transferred in 29/34 (85.3\%) such events. Gentamicin resistance was transferred in 17/34 (50\%) of events. Conclusions: Majority of plasmids carrying bla $a_{\mathrm{CTX}-\mathrm{M}-15}$ were conjugatively transferred by IncF plasmids along with non-beta lactam resistance. There is a need for more research on plasmids to understand how plasmids especially multi replicon plasmids interact and the effect of such interaction on conjugation. One Health approach is to be intensified to address antimicrobial resistance which is a public health threat.
\end{abstract}

Keywords: conjugation; CTX-M-15; replicon; plasmid; non-beta lactam antibiotics; One Health

\section{Introduction}

The increasing trend of antimicrobial resistance is intensified by mobile genetic elements that harbour resistance genes [1]. The effect of these elements is extensively reported among bacteria of the Enterobacteriaceae family where multi drug resistance (MDR) is high. The CTX-M extended-spectrum beta-lactamases (ESBL) are the most successful MDR determinants [2], with over 100 alleles in five distinct phylogenetic groups [3]. The ecological success of CTX-M-ESBL attributes to the enzymes' spread both clonally and horizontally [3-5] in multiple hosts that include Acinetobacter spp., Enterobacter spp., E. coli, $P$. aeruginosa, K. pneumoniae and P. mirabilis.

In natural environments, ESBL enzymes are chromosomally mediated by the selection pressure induced by beta-lactamase-producing soil organisms [6,7] or the irrational use 
of third-generation cephalosporins [6,8], however as previously reviewed [9], plasmidmediated ESBL resulted from transposon-mediated insertion of different $b_{1} a_{\mathrm{CTX}-\mathrm{M}}$ genes in bacteria chromosome. Specifically, the precursors of plasmid-mediated $b l a_{\mathrm{CTX}-\mathrm{M}-15}$ are environmental Kluyvera spp. whose chromosomal CTX-M clusters are incorporated into the chromosome of host bacteria by mobilising elements such as ISEcp1 or ISCR1. Moreover, the location of ISEcp 1 upstream $b l a_{\mathrm{CTX}-\mathrm{M}}$ genes together with multiple inverted repeats downstream the gene facilitates the expression and ongoing transposition of bla $a_{K L U}$ genes that result to various CTX-M enzymes, including plasmid-mediated bla $a_{\text {CTX-M-15 }}[9,10]$. The mobilisation potential of ISEcp 1 for chromosome-linked multi-resistant determinants in other members of enterobacteriaceae increases with the additional possession of ISCR1, another mobile genetic element (MGE) embedded in a Class 1 integron that mobilises unrelated CTX-M groups in similar or different species.

As vectors and carriers of AMR genes, plasmids are responsible for the intracellular accumulation and intercellular transfer of these genes by the process of conjugation [11]. In such cases, high conjugation rates ensure the stable long-term persistence of plasmids and associated AMR genes in minimal fitness costs even in the absence of selection pressure [12-14]. A multidrug resistance phenomenon is observed when these plasmids are associated with other MGE possessing different resistance determinants and code for adaptive traits such as virulence or metal resistance genes among host bacteria strains $[15,16]$.

The globally disseminated O25: H4-ST131 E. coli clone producing CTX-M-15 is by conjugative IncF plasmids that are frequently recovered from hospital and community settings [17]. In Tanzania, the prevalence of bacteria producing ESBL ranges between 25 and 50 percent [18], with $b l a_{\mathrm{CTX}-\mathrm{M}-15}$ as the predominant allele in both community [19] and hospital settings [20]. The gene is also observed among companion and domestic animals and the environment combined with quinolone and aminoglycoside resistance genes [21,22]. Therefore, as demonstrated by its discovery in a novel Enterobacter spp. [23] and location in multiple plasmid types such as IncF, IncY and IncHI1, there is a possibility of an extensive variation in the epidemiology of $b l_{\mathrm{CTX}-\mathrm{M}-15}$ carrying plasmids in Tanzania.

The presence of bla $a_{\mathrm{CTX}-\mathrm{M}-15}$ gene in multiple E.coli clones of human, animal and the environment of Tanzania [24], and limited information on the persistence of the gene's alleles in any compartments can lead to the acquisition, transmission and evolution of new resistant strains even among non-conjugative bacteria. Since plasmids facilitate the spread of AMR genes in different compartments efforts to understand their spread and establishment in these settings is unquestionable. This study has improved our understanding of the importance of IncF plasmids in disseminating multidrug-resistant determinants among human, animal and environmental settings. It has further highlighted the importance of collaborative One Health based efforts that focus on animal and human health as critical when addressing the global threat.

\section{Results}

\subsection{Isolates Characteristics}

Escherichia coli was the only species isolated in both human and animals. The environment included isolates from soil and fresh water fish and comprised of E. coli, K. pneumoniae, C. braakii and E. cloacae species (Table 1).

\subsection{Conjugation Efficiency of bla ${ }_{C T X-M-15}$ Gene among Isolates of Human, Animals and the Environment}

Among 51 bla $_{\text {CTX-M-15 }}$ positive donor isolates, 45 (88.2\%) transferred plasmids by conjugation with a transfer rate (transconjugants per donor cells) ranging from $4.8 \times 10^{-1}$ to $1.5 \times 10^{-9}$ as observed from a human and environment isolate, respectively (Table 2). 
Table 1. Bacteria species distributed among donor isolates of human, animal and environment.

\begin{tabular}{|c|c|c|c|c|c|}
\hline $\begin{array}{l}\text { Sample } \\
\text { Origin }\end{array}$ & Sample Type & $\begin{array}{c}\text { Frequency } \\
\mathbf{n} \%\end{array}$ & Species & $\begin{array}{c}\text { Species n } \\
(\%)\end{array}$ & Total n (\%) \\
\hline \multirow[t]{2}{*}{ Human } & Human & $22(43.14)$ & E. coli & $22(43.1)$ & $22(43.14)$ \\
\hline & Goat & 1 (1.96) & E. coli & $1(1.96)$ & \\
\hline \multirow[t]{3}{*}{ Animal } & Pig & $3(5.88)$ & E. coli & $3(5.88)$ & \\
\hline & Dog & $6(11.76)$ & E. coli & $6(11.76)$ & $12(23.52)$ \\
\hline & Chicken & $2(3.92)$ & E. coli & $2(3.92)$ & \\
\hline \multirow[t]{5}{*}{ Environment } & Soil & $6(11.76)$ & E. coli & $6(11.76)$ & \\
\hline & & & E. coli & $2(3.92)$ & \\
\hline & Fish & 11 (21.57) & К. pneumoniae & $3(5.88)$ & 17 (33.32) \\
\hline & & & C. braakii & $2(3.92)$ & \\
\hline & & & E. cloacae & $4(7.84)$ & \\
\hline Total (n) & & $51(100)$ & & & $51(100)$ \\
\hline
\end{tabular}

Table 2. Conjugation efficiency of human, animal and environment donor isolates.

\begin{tabular}{|c|c|c|c|}
\hline Sample ID & Source & Species & Conjugation Frequency \\
\hline CN1 & Fish & E. cloacae & $8.2 \times 10^{-5}$ \\
\hline $\mathrm{CN} 2$ & Fish & E. cloacae & $2.3 \times 10^{-4}$ \\
\hline $\mathrm{CN} 3$ & Fish & E. cloacae & $5.2 \times 10^{-5}$ \\
\hline $\mathrm{CN} 4$ & Fish & E. cloacae & NIL \\
\hline CN5 & Fish & C. braakii & $7.5 \times 10^{-6}$ \\
\hline CN6 & Fish & E. coli & $7.6 \times 10^{-3}$ \\
\hline CN7 & Fish & E. coli & NIL \\
\hline $\mathrm{CN} 8$ & Fish & K. pneumoniae & $2.0 \times 10^{-5}$ \\
\hline CN9 & Fish & K. pneumoniae & $4.2 \times 10^{-4}$ \\
\hline CN10 & Fish & K. pneumoniae & $3.3 \times 10^{-5}$ \\
\hline CN11 & Fish & C. braakii & $9.4 \times 10^{-4}$ \\
\hline CN12 & Pig & E. coli & $4.7 \times 10^{-5}$ \\
\hline CN13 & Pig & E. coli & $2.6 \times 10^{-6}$ \\
\hline CN14 & Pig & E. coli & $9.8 \times 10^{-5}$ \\
\hline CN15 & Local chicken & E. coli & $4.7 \times 10^{-5}$ \\
\hline CN16 & Local chicken & E. coli & $8.4 \times 10^{-7}$ \\
\hline CN17 & Goat & E. coli & $4.1 \times 10^{-6}$ \\
\hline CN18 & Dog & E. coli & $2.1 \times 10^{-5}$ \\
\hline CN19 & Dog & E. coli & $1.2 \times 10^{-7}$ \\
\hline $\mathrm{CN} 20$ & Dog & E. coli & $5.0 \times 10^{-5}$ \\
\hline CN21 & Dog & E. coli & $1.1 \times 10^{-6}$ \\
\hline $\mathrm{CN} 22$ & Dog & E. coli & $6.0 \times 10^{-4}$ \\
\hline $\mathrm{CN} 23$ & Dog & E. coli & $9.6 \times 10^{-6}$ \\
\hline $\mathrm{CN} 24$ & Environment & E. coli & $1.5 \times 10^{-9}$ \\
\hline CN25 & Environment & E. coli & $2.6 \times 10^{-7}$ \\
\hline CN26 & Environment & E. coli & $3.5 \times 10^{-6}$ \\
\hline CN27 & Environment & E. coli & $2.9 \times 10^{-7}$ \\
\hline $\mathrm{CN} 28$ & Environment & E. coli & $6.1 \times 10^{-6}$ \\
\hline CN29 & Environment & E. coli & $7.2 \times 10^{-3}$ \\
\hline $\mathrm{CN} 30$ & Human & E. coli & $1.0 \times 10^{-3}$ \\
\hline CN31 & Human & E. coli & $4.7 \times 10^{-4}$ \\
\hline CN32 & Human & E. coli & $2.1 \times 10^{-4}$ \\
\hline CN33 & Human & E. coli & $4.0 \times 10^{-5}$ \\
\hline CN34 & Human & E. coli & $5.4 \times 10^{-5}$ \\
\hline CN35 & Human & E. coli & $4.8 \times 10^{-1}$ \\
\hline CN36 & Human & E. coli & $1.7 \times 10^{-4}$ \\
\hline CN37 & Human & E. coli & $3.5 \times 10^{-7}$ \\
\hline CN38 & Human & E. coli & $8.1 \times 10^{-5}$ \\
\hline CN39 & Human & E. coli & $1.2 \times 10^{-5}$ \\
\hline
\end{tabular}


Table 2. Cont.

\begin{tabular}{cccc}
\hline Sample ID & Source & Species & Conjugation Frequency \\
\hline CN40 & Human & E. coli & $2.7 \times 10^{-5}$ \\
CN41 & Human & E. coli & $2.4 \times 10^{-7}$ \\
CN42 & Human & E. coli & NIL \\
CN43 & Human & E. coli & $5.5 \times 10^{-6}$ \\
CN44 & Human & E. coli & $4.4 \times 10^{-6}$ \\
CN45 & Human & E. coli & $2.9 \times 10^{-6}$ \\
CN46 & Human & E. coli & NIL \\
CN47 & Human & E. coli & $2.1 \times 10^{-5}$ \\
CN48 & Human & E. coli & $1.2 \times 10^{-4}$ \\
CN49 & Human & E. coli & $1.1 \times 10^{-7}$ \\
CN50 & Human & E. coli & NIL \\
CN51 & Human & E. coli & NIL \\
\hline
\end{tabular}

NIL: no conjugation.

2.3. Transferrable Resistance of Non-Beta-Lactam Phenotype among Isolates of Human, Animal and the Environment

Table 3 and Figure 1 presents a summary of non-beta lactam resistant phenotypes transferred along the bla CTX-M-15 gene. A total of 45 plasmids successful transferred the gene to transconjugants. Non-beta-lactam resistance phenotypes were observed in $34 / 45(75.6 \%)$ transconjugants. Donor resistance to ciprofloxacin (CIP), tetracycline (TE) and trimethoprim-sulphamethoxazole (SXT) was observed in 46/51 (90.2\%), 47/51 (92.2\%) and $48 / 51$ (94.1\%) of events, respectively, and was co-transferred in 29/34 (85.3\%) of such events. Gentamicin was the least transferred with a frequency of $17 / 34(50.0 \%)$.

Table 3. Antibiotic resistance phenotypes of donors and transconjugants of human animals and the environment.

\begin{tabular}{|c|c|c|c|}
\hline Sample No. & Source & Species & $\begin{array}{l}\text { Donor's Non-B-lactam } \\
\text { Resistance Phenotype }\end{array}$ \\
\hline CN1 & Fish & E. cloacae & $\mathrm{SXT}^{*}, \mathrm{CIP} *, \mathrm{CN}^{*}, \mathrm{TE}^{*}$ \\
\hline CN2 & Fish & E. cloacae & CIP, SXT, CN, TE \\
\hline $\mathrm{CN} 3$ & Fish & E. cloacae & $\mathrm{CIP}^{*}, \mathrm{SXT}^{*}, \mathrm{TE}^{*}, \mathrm{CN}^{*}$ \\
\hline $\mathrm{CN} 4$ & Fish & E. cloacae & CIP, CN, TE, SXT \\
\hline CN5 & Fish & C. braakii & $\mathrm{CIP}^{*}, \mathrm{SXT}^{*}, \mathrm{CN}^{*}, \mathrm{TE} *$ \\
\hline CN6 & Fish & E. coli & CIP, SXT, CN, TE \\
\hline CN7 & Fish & E. coli & $\mathrm{CIP}, \mathrm{TE}$ \\
\hline $\mathrm{CN} 8$ & Fish & K. pneumoniae & $\mathrm{CIP} *, \mathrm{SXT}^{*}, \mathrm{CN}^{*}, \mathrm{TE} *$ \\
\hline CN9 & Fish & K. pneumoniae & $\mathrm{CIP} *, \mathrm{SXT}^{*}, \mathrm{CN} *, \mathrm{TE} *$ \\
\hline CN10 & Fish & K. pneumoniae & CIP, SXT, CN, TE \\
\hline CN11 & Fish & C. braakii & CIP, SXT, CN, TE * \\
\hline CN12 & Pig & E. coli & $\mathrm{CIP}^{*}, \mathrm{SXT} *, \mathrm{TE}^{*}$ \\
\hline CN13 & Pig & E. coli & TE, CIP, CN \\
\hline CN14 & Pig & E. coli & $\mathrm{CIP}^{*}, \mathrm{SXT}^{*}, \mathrm{TE}^{*}, \mathrm{CN}^{*}$ \\
\hline CN15 & Local chicken & E. coli & CIP, SXT, CN, TE \\
\hline CN16 & Local chicken & E. coli & CIP, SXT, CN, TE \\
\hline CN17 & Goat & E. coli & $\mathrm{SXT}, \mathrm{TE} *, \mathrm{CN}, \mathrm{CIP} *$ \\
\hline CN18 & Dog & E. coli & SXT \\
\hline CN19 & Dog & E. coli & $\mathrm{SXT}^{*}, \mathrm{CIP} *, \mathrm{TE}, \mathrm{CN}$ \\
\hline CN20 & Dog & E. coli & $\mathrm{CIP}^{*}, \mathrm{SXT}^{*}, \mathrm{TE}^{*}$ \\
\hline CN21 & Dog & E. coli & $\mathrm{CIP}^{*}, \mathrm{SXT}^{*}, \mathrm{TE}^{*}, \mathrm{CN}^{*}$ \\
\hline $\mathrm{CN} 22$ & Dog & E. coli & $\mathrm{CIP} *, \mathrm{CN}^{*}, \mathrm{TE}^{*}, \mathrm{SXT} *$ \\
\hline $\mathrm{CN} 23$ & Dog & E. coli & SXT, TE, CN, CIP \\
\hline $\mathrm{CN} 24$ & Environment & E. coli & $\mathrm{SXT}^{*}, \mathrm{CIP} *, \mathrm{TE}^{*}$ \\
\hline CN25 & Environment & E. coli & SXT, TE, CIP \\
\hline CN26 & Environment & E. coli & $\mathrm{CIP}^{*}, \mathrm{SXT}^{*}, \mathrm{TE}^{*}$ \\
\hline
\end{tabular}


Table 3. Cont.

\begin{tabular}{|c|c|c|c|}
\hline Sample No. & Source & Species & $\begin{array}{l}\text { Donor's Non-B-lactam } \\
\text { Resistance Phenotype }\end{array}$ \\
\hline CN27 & Environment & E. coli & $\mathrm{CIP} *$ \\
\hline CN28 & Environment & E. coli & $\mathrm{CIP}^{*}, \mathrm{SXT}^{*}, \mathrm{CN}^{*}, \mathrm{TE}^{*}$ \\
\hline CN29 & Environment & E. coli & $\mathrm{CN}, \mathrm{CIP} *, \mathrm{SXT}^{*}, \mathrm{TE} *$ \\
\hline CN30 & Human & E. coli & $\mathrm{TE}^{*}, \mathrm{CIP} *, \mathrm{CN}, \mathrm{SXT} *$ \\
\hline CN31 & Human & E. coli & $\mathrm{CIP} *, \mathrm{SXT} *$ \\
\hline CN32 & Human & E. coli & $\mathrm{SXT}^{*}, \mathrm{CIP} *$ \\
\hline $\mathrm{CN} 33$ & Human & E. coli & $\mathrm{TE}^{*}, \mathrm{CN}^{*}, \mathrm{CIP} *, \mathrm{SXT}^{*}$ \\
\hline CN34 & Human & E. coli & $\mathrm{SXT}^{*}, \mathrm{TE}^{*}, \mathrm{CN}^{*}, \mathrm{CIP}$ \\
\hline CN35 & Human & E. coli & $\mathrm{CIP}^{*}, \mathrm{CN}^{*}, \mathrm{SXT}^{*}, \mathrm{TE} *$ \\
\hline CN36 & Human & E. coli & $\mathrm{CIP}^{*}, \mathrm{CN}^{*}, \mathrm{SXT}^{*}, \mathrm{TE}^{*}$ \\
\hline CN37 & Human & E. coli & $\mathrm{CIP}^{*}, \mathrm{CN}^{*}, \mathrm{SXT}^{*}, \mathrm{TE}^{*}$ \\
\hline CN38 & Human & E. coli & $\mathrm{SXT}^{*}, \mathrm{TE}^{*}, \mathrm{CIP}^{*}, \mathrm{CN}^{*}$ \\
\hline CN39 & Human & E. coli & $\mathrm{SXT}, \mathrm{TE}, \mathrm{CIP} *, \mathrm{CN} *$ \\
\hline $\mathrm{CN} 40$ & Human & E. coli & $\mathrm{SXT}^{*}, \mathrm{TE}^{*}$ \\
\hline CN41 & Human & E. coli & $\mathrm{SXT}, \mathrm{TE}^{*}, \mathrm{CIP} *, \mathrm{CN}$ \\
\hline $\mathrm{CN} 42$ & Human & E. coli & SXT, CIP, CN, TE \\
\hline CN43 & Human & E. coli & $\mathrm{CN}^{*}, \mathrm{CIP} *, \mathrm{SXT}^{*}, \mathrm{TE}^{*}$ \\
\hline CN44 & Human & E. coli & SXT, TE, CIP \\
\hline CN45 & Human & E. coli & SXT, TE, CIP, CN \\
\hline CN46 & Human & E. coli & TE, SXT \\
\hline CN47 & Human & E. coli & $\mathrm{SXT}^{*}, \mathrm{TE} *, \mathrm{CIP}, \mathrm{CN}$ \\
\hline CN48 & Human & E. coli & $\mathrm{SXT}^{*}, \mathrm{TE}^{*}, \mathrm{CIP}, \mathrm{CN}$ \\
\hline CN49 & Human & E. coli & $\mathrm{CIP}^{*}, \mathrm{CN}^{*}, \mathrm{SXT}^{*}, \mathrm{TE} *$ \\
\hline CN50 & Human & E. coli & SXT, TE \\
\hline CN51 & Human & E. coli & CN, CIP, SXT, TE \\
\hline
\end{tabular}
$\mathrm{CN}$ : Gentamicin.

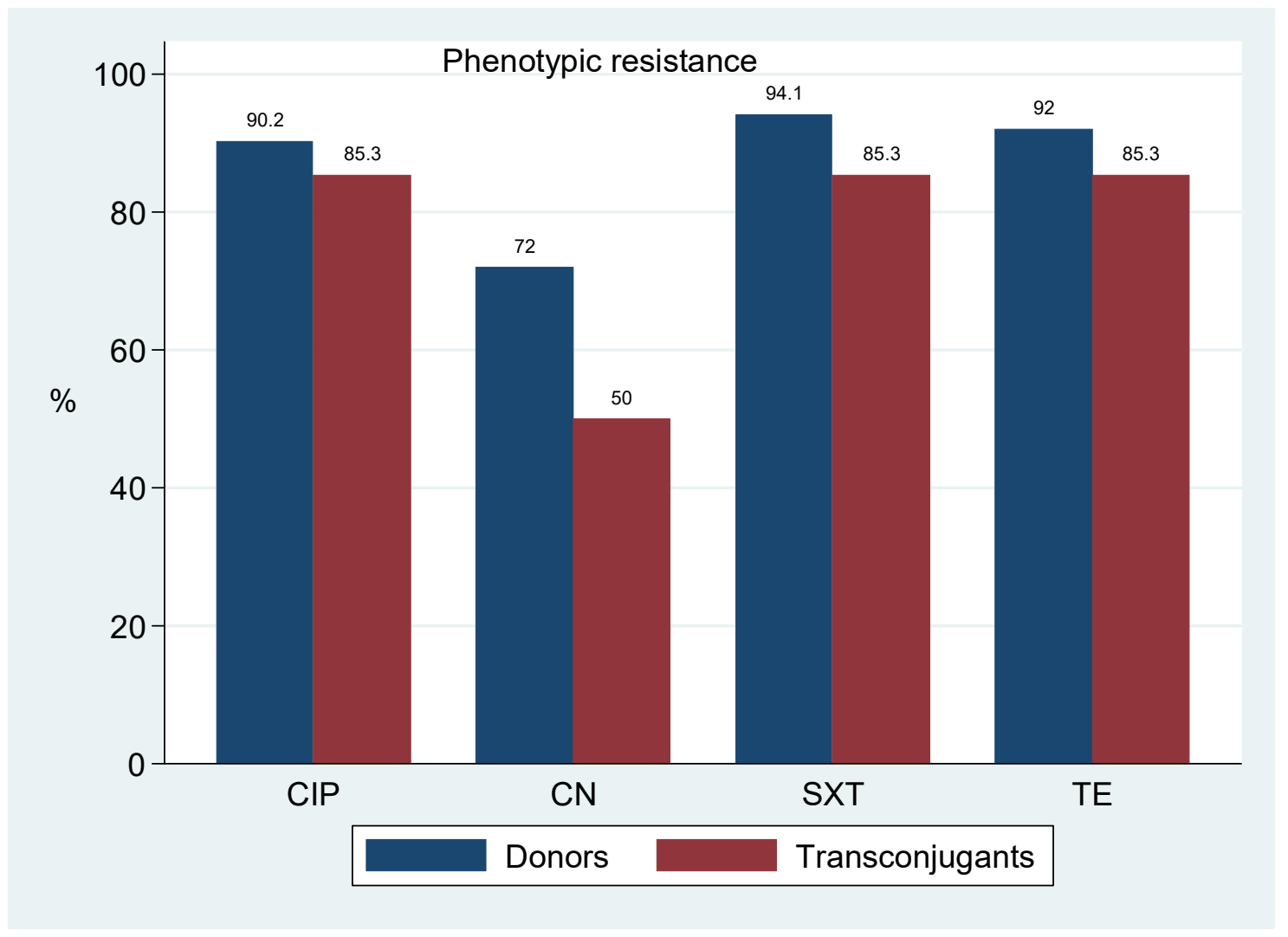

Figure 1. Transfer success of bla $a_{\mathrm{CTX}-\mathrm{M}-15}$ among E. coli isolates of human, animals and the environment. 


\subsection{Replicon Types of Plasmids Carrying bla}

Common replicon types were FIA $(n=11)$ and FIB $(n=27)$ that occurred as single transferrable replicons in 14 events. Inc $\mathrm{A} / \mathrm{C}$ and $\mathrm{Y}$ replicons were minor, and each was typed once. Of all the 14 typed transconjugant plasmids, 7 replicons were observed in both donors and transconjugants, while 20/27 donor replicons were not observed in respective transconjugants (Table 4), (Figure 2).

Table 4. Replicon types of plasmids carrying $b{ } a_{\mathrm{CTX}-\mathrm{M}-15}$ among donors and transconjugants.

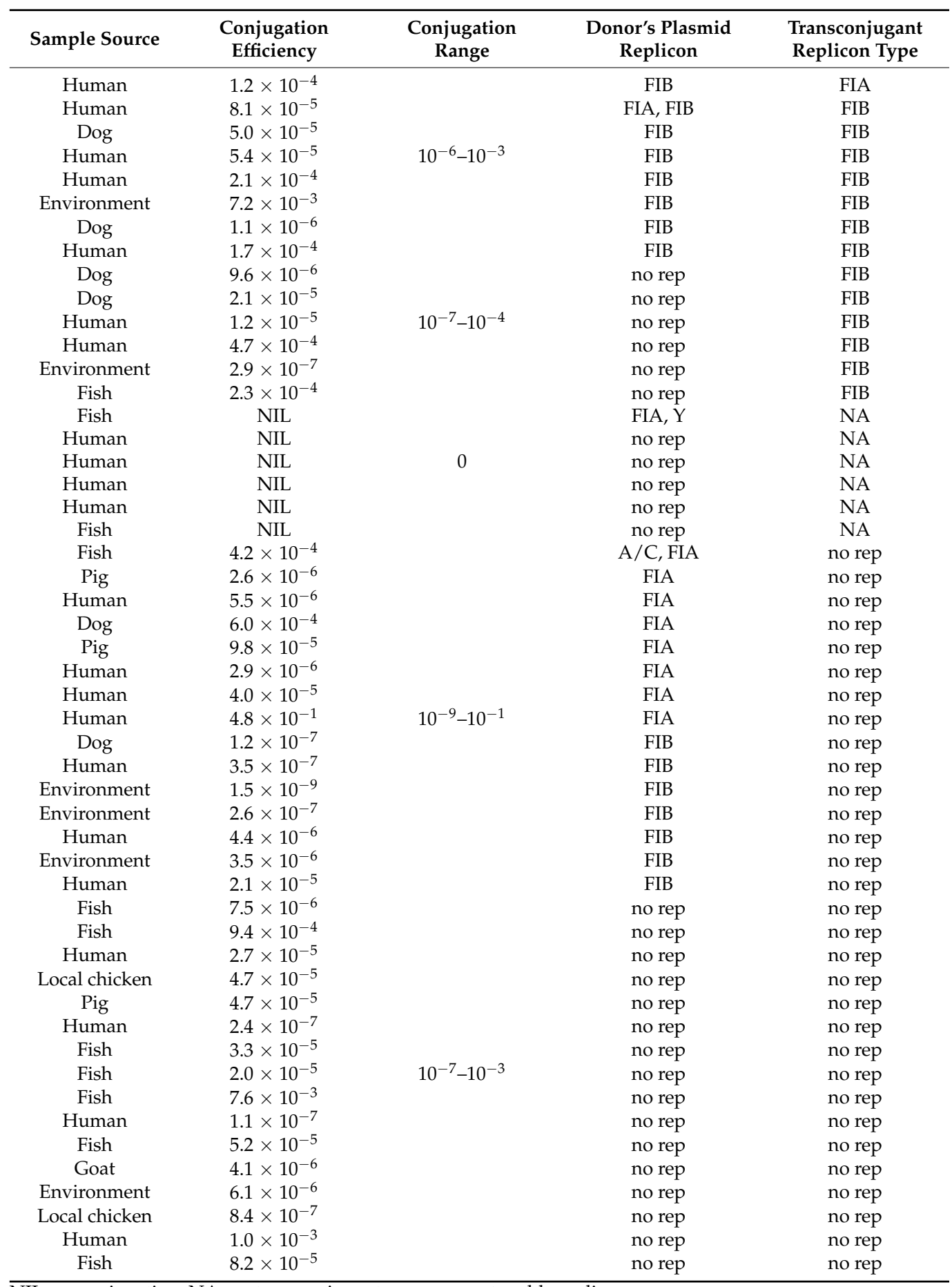

NIL: no conjugation, NA: no transconjugants, no rep: no typable replicon. 


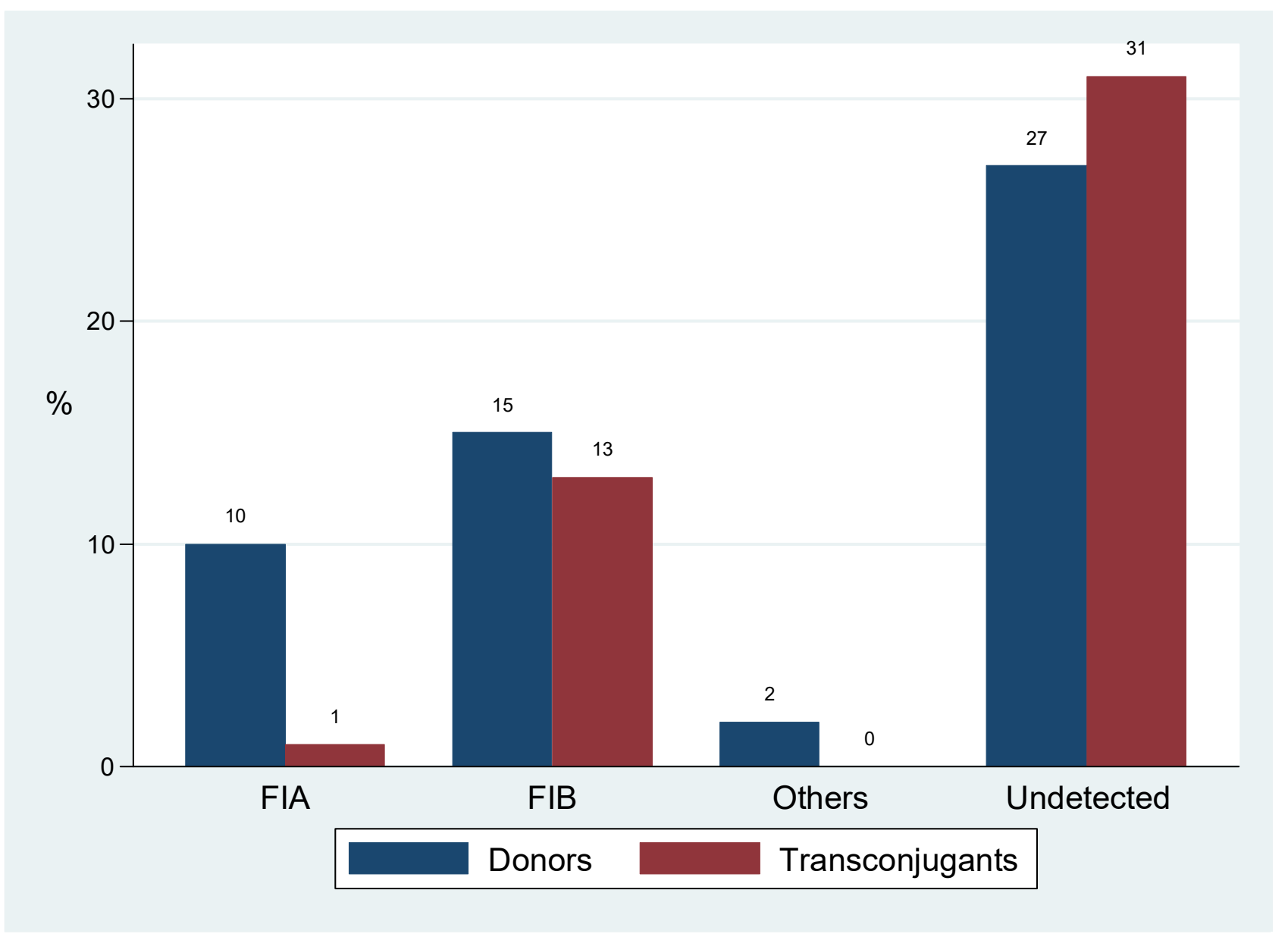

Figure 2. Replicon types of plasmids carrying $b l a_{\mathrm{CTX}-\mathrm{M}-15}$ among donors and transconjugants.

\subsection{Transfer Success of bla}

Table 5 shows the percentage transfer of bla $a_{\mathrm{CTX}-\mathrm{M}-15}$ among E. coli donor isolates. Out of $42 \mathrm{E}$. coli donors, 37 (88.1\%) successfully transferred the gene, accounting for an $82.1 \%$ of all transconjugants. All E. coli originating from animals transferred the gene successfully.

Table 5. Transfer success of bla $a_{\mathrm{CTX}-\mathrm{M}-15}$ among $E$. coli isolates of human, animals and the environment.

\begin{tabular}{ccc}
\hline Source & $\begin{array}{c}\text { E. coli Donors } \\
\mathbf{n}\end{array}$ & $\begin{array}{c}\text { E. coli Transconjugants } \\
\mathbf{n}(\%)\end{array}$ \\
\hline Human & 22 & $18(81.8)$ \\
Animal & 12 & $12(100.0)$ \\
Environment & 8 & $7(87.5)$ \\
Total & 42 & $37(88.1)$ \\
\hline
\end{tabular}

\section{Discussion}

In this study, we aimed to determine conjugation frequencies and type plasmids carrying the $b l a_{\mathrm{CTX}-\mathrm{M}-15}$ gene from human, animal and environment ESBL producing isolates. The study is epidemiologically important in understanding the pattern and possibly predict the flow of AMR from different sources. As presented in (Table 1), Escherichia coli was the dominant bacteria species from all sourced samples. The successful colonisation of $E$. coli in human and animal gastrointestinal tract (GIT) have been reported previously [25], the GIT can serve as exchange hotspots and reservoirs of antimicrobial resistance genes. Likewise, Escherichia coli and Klebsiella pneumoniae are frequently isolated in infections associated 
with CTX-M-15 in hospitals [26] and the community, including households [27], aquatic environment [28] and the soil [29].

The transfer efficiency of $b l_{\mathrm{CTX}-\mathrm{M}-15}$ among isolates in this study was higher $(88 \%)$ [Table 2], than that reported by Zurfluh and colleagues [30], where a $38.3 \%$ efficiency was observed, however, despite the varying frequencies of transfer, the reported efficiency is slightly lower than that previously reported $(100 \%)$ for randomly selected hospital originating isolates [20]. It is reported that high conjugation rates above thresholds compensate fitness costs and establish a long-term persistence of plasmids in multiple hosts $[13,31,32]$ through maintaining successive generations of bacteria with adaptive traits. Therefore, the high transfer efficiency is a fitness advantage that improves the persistence and dissemination potential of bla $a_{\mathrm{CTX}-\mathrm{M}-15}$ ESBL in human, animal and the environment interface. Moreover, transfer failure for some isolates- CN4, CN7, CN42, CN46, CN50 and CN51, could possibly be due to the gene's integration in the chromosome [33] or transposition events that prevent plasmid mobility.

As summarised in Table 3 and Figure 1, transferable multidrug resistance phenotypes were also observed. The conjugative spread of $b l a_{\mathrm{CTX}} \mathrm{M}-15$ gene by IncF plasmids along with tetracycline, aminoglycoside and quinolones have been reported [34]. These plasmids harbor several combinations of resistance determinants and transfer them to human, animals and environment isolates through the ecological interaction of bacteria in these settings. Moreover, the genetic environment of bla $a_{\mathrm{CTX}-\mathrm{M}-15}$ is dominated by multiple antibiotic resistance genes such as aac $\left(6^{\prime}\right)-l b-c r$, tet $(A, B)$, qnrS, qnr and sul genes [35-37], whose phenotypic expression denotes the existing selection pressure for these antibiotics. Such selection can increase their transfer rate and possibly account for the high co-transfer of non-beta lactam antibiotics observed in this study.

We also observed single replicon IncF plasmids as common vectors of bla CTXM-15, (Table 4), (Figure 2). Replicon typing of plasmids carrying antimicrobial resistance genes is important for detecting, tracing or monitoring the spread of antimicrobial resistance. These observations are in line with findings in the same setting [20] and elsewhere [30,38] where multireplicon FIA and FIB plasmids were reported to carry multiple resistance genes including $b l a_{\mathrm{CTX}-\mathrm{M}-15}$. As in previous studies, IncY plasmids and Inc A/C carrying bla $a_{\mathrm{CTX}-\mathrm{M}-15}$ in association with quinolone and aminoglycoside genes were also reported [22], [39,40]. Together these findings support the diverse nature of plasmids adapted to spread and maintain $b l a_{\mathrm{CTXM}-15}$ gene.

The absence of donor replicons in respective transconjugants might have resulted from conjugation failure, multi-replicons (undetected by the method used) that destabilise and prevent the transfer of some resident replicons [41], and prior plasmid dependent mutations (which do not occur in transconjugants) that may have altered backbone genes of donor plasmids and obscure the detection of existing replicons $[32,39,41]$. In addition, and as a shortcoming, the PBRT technique used in detecting plasmid replicons can give false-negative results when replicon sequences go undetected by the primer sets used, target replicon sequences undergo mutation through transpositional alterations and the unknown existence of new replicons in such plasmid [42].

Lastly, we observed that all animal originating $E$. coli isolates transferred $b l a_{\mathrm{CTX}-\mathrm{M}-15}$ to respective transconjugants (Table 5), (Figure 3). These findings were also supported by a recent review [34], that human and animal originating E.coli are adapted to disseminate ESBL genes by IncF plasmids. The colonisation and infection of animals by E. coli maximises microbial interactions between non-pathogenic and pathogenic commensal E.coli in either companion or food-producing animals and facilitate the exchange of materials between them through conjugation. In addition, the increasing use of antibiotics in animals could select and transfer resistant pathogenic bacteria from animals to human and the environment with huge cost implications. Since AMR is a public health threat, the highest transfer rate observed in animal originating $E$. coli calls for integrated efforts to address AMR with experts from veterinary, human and ecological fields. It further implies that 
animals may serve as dual targets for studies focusing on the horizontal transfer and evolution of antimicrobial resistance.

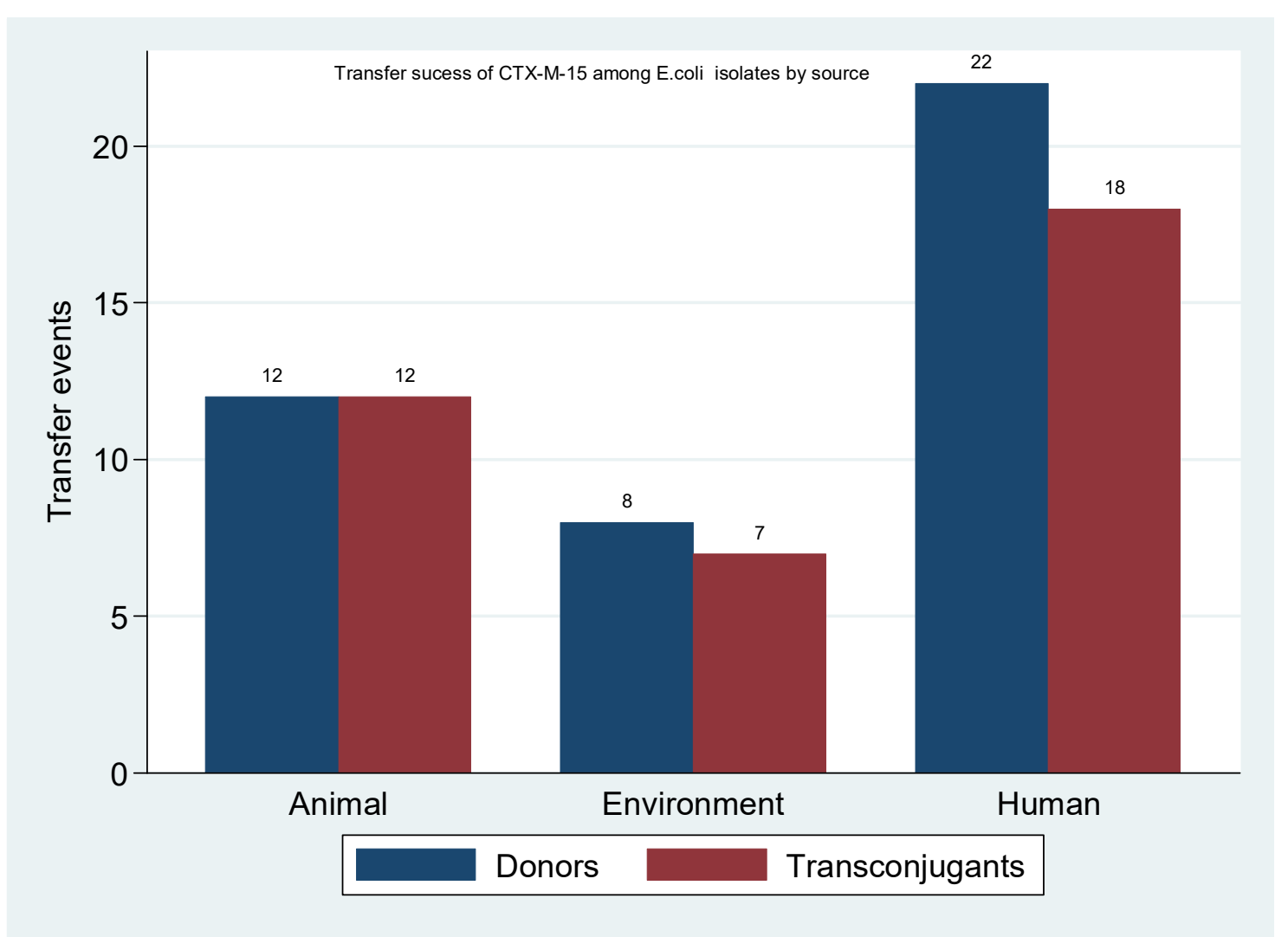

Figure 3. Transfer success of bla $a_{\mathrm{CTX}-\mathrm{M}-15}$ among E. coli isolates of human, animals and the environment.

\section{Materials and Methods}

\subsection{Study Isolates}

All isolates used as donors in this study were obtained from the Catholic University of Health and Allied Sciences (CUHAS) in Mwanza Tanzania. A total of 51 bla CTX-M-15 positive isolates were purposively selected and activated overnight in Luria Bertani (LB) broth at $37^{\circ} \mathrm{C}$ ready for use in conjugation and PBRT techniques.

Among the 51 isolates, twenty-two $b l a_{\mathrm{CTX}-\mathrm{M}-15}$ positive isolates were obtained from a study that reported the magnitude of fecal carriage and diversity of ESBL genotypes among human residing in rural communities of Mwanza Tanzania [19], 12 other bla $a_{\mathrm{CTX}-\mathrm{M}-15}$ positive isolates were from a study that reported the fecal carriage of ESBL among companion and domestic farm animals that included pigs, chicken, dogs and goats [21]. The remaining 17 environmental isolates were obtained from a study that investigated the presence of $b l a_{\mathrm{CTX}-\mathrm{M}-15}$ from muddy soils and gut contents of freshwater fish from Lake Victoria in Mwanza Tanzania [22].

\subsection{Antibiotic Susceptibility Testing}

Susceptibility testing of all donor isolates and the resulting transconjugants was performed by the disk diffusion method on Mueller Hinton agar as recommended by the Clinical and Laboratory Standard Institute [43]. Antibiotics tested were tetracycline $(30 \mu \mathrm{g})$, gentamicin $(30 \mu \mathrm{g})$, ciprofloxacin $(5 \mu \mathrm{g})$ and trimethoprim/sulphamethoxazole $(1.25 / 23.75 \mu \mathrm{g})($ Hi-media, India). 


\subsection{Conjugation Experiment}

A total of 51 known bla $a_{C T X-M-15}$ positive isolates and Escherichia coli $\mathrm{J} 53\left(\left(\mathrm{~F}^{-}\right.\right.$, met, pro, $A z^{r}$ )-a mutant strain of E. coli [44] obtained from the Institute of Medical Microbiology, Giessen, Germany, were used as donors and recipient strain, respectively. As previously described [20], we performed conjugation experiments with some modifications. Shortly, the recipient strain was prepared by streaking Escherichia coli J53 in Luria Bertani (LB) plates supplemented with $100 \mu \mathrm{g} / \mathrm{mL} \mathrm{NaN}_{3}(\mathrm{LB}++)$, while donor strains were selected in LB plates supplemented with $2 \mu \mathrm{g} / \mathrm{mL}$ cefotaxime only (LB+). From these, fresh overnight donor and recipient strains were prepared by picking single colonies emulsified in $10 \mathrm{~mL}$ LB broth and incubated overnight at $37^{\circ} \mathrm{C}$ in a $150 \mathrm{rpm}$ shaking incubator. After exactly $12 \mathrm{~h}$, equal volumes $(500 \mu \mathrm{L})$ of donor and recipient strains were immediately mixed in $1.5 \mathrm{~mL}$ eppendorf tubes previously labeled transconjugant (Tc) while $1000 \mu \mathrm{L}$ of donor strain were added in fresh tubes of similar volume-to be separately selected on LB+ and $\mathrm{LB}++$ plates as respective controls. All tubes were incubated at $37^{\circ} \mathrm{C}$ for $15 \mathrm{~min}$, vortexed briefly, centrifuged at 12,000 g for $2 \mathrm{~min}$ and the pellet re-suspended in fresh $1000 \mu \mathrm{L}$ LB broth. Finally, $0.1 \mathrm{~mL}$ of $10^{-1}$ to $10^{-4}$ transconjugant cultures were double selected on LB plates supplemented with $100 \mu \mathrm{g} / \mathrm{mL} \mathrm{NaN}_{3}$ and $2 \mu \mathrm{g} / \mathrm{mL}$ cefotaxime. Conjugation efficiency was reported as transconjugants per donor cells, with the denominator obtained from an initial volume of $100 \mu \mathrm{L}$.

\subsection{Genomic Extraction of Donor and Transconjugants DNA}

Donor and transconjugant genomic DNA was extracted using a previously described chelex protocol with slight modifications [45]. First, $5 \mu \mathrm{L}$ of proteinase $\mathrm{K}(10 \mathrm{mg} / \mathrm{mL})$ were added into tubes containing $100 \mu \mathrm{L}$ fresh LB emulsified colonies. In the same tubes, $300 \mu \mathrm{L}$ of chelex buffer (Qiagen $\mathrm{GmbH}$, Hilden, Germany) was added consecutively. The mixture was incubated for $3 \mathrm{hr}$ at $55^{\circ} \mathrm{C}$ before adding $85 \mu \mathrm{L}$ of $5 \mathrm{M} \mathrm{NaCl}$ and vortexed for $15 \mathrm{~s}$ to precipitate proteins. The supernatant was centrifuged at $13,000 \times \mathrm{g}$ for $10 \mathrm{~min}$ followed by the addition of $300 \mu \mathrm{L}$ of $100 \%$ cold ethanol and a 5 min centrifugation at $13,000 \times g$ that precipitated and pelleted the DNA. Lastly, the pellet was rinsed by pouring off the remaining fluid, adding $500 \mu \mathrm{L}$ of $70 \%$ ethanol, centrifuging at $13,000 \times g$ for $5 \mathrm{~min}$ and leaving the pellet to air dry at $55^{\circ} \mathrm{C}$ for $10 \mathrm{~min}$. The DNA was then re-suspended in $50 \mu \mathrm{L}$ nuclease-free water. Nanodrop (Thermo Scientific, Wilmington, DE) was used to check the quantity of the DNA, while the quality was confirmed by electrophoresis in $1.5 \%(w / v)$ agarose gel using TAE buffer. The obtained DNA samples were used in typing plasmid replicons or stored at $-20^{\circ} \mathrm{C}$.

\subsection{PCR Based Replicon Typing}

Targeted genes were amplified by a simplified version of the previously described PBRT technique [42]. Shortly, the eight Polymerase Chain Reaction (PCR) panels illustrated by Caratolli and colleagues [46], were reduced to three [42], (Table 6). PCR was performed using a readily reconstituted master mix according to manufacturer's instructions (New England BioLabs, Inc. Beverly, MA) under the following conditions; 5 min at $94{ }^{\circ} \mathrm{C} ; 30$ cycles of $30 \mathrm{~s}$ at $94{ }^{\circ} \mathrm{C}, 30 \mathrm{~s}$ at $60{ }^{\circ} \mathrm{C}$ and $90 \mathrm{~s}$ at $72{ }^{\circ} \mathrm{C}$; then a final extension of $5 \mathrm{~min}$ at $72{ }^{\circ} \mathrm{C}$. Amplicons were visualised on $1.5 \%$ tris-acetate EDTA agarose gels alongside a 100 bp DNA ladder (New England BioLabs, Inc. Beverly, MA). The sample was considered positive for replicon gene (s) if an amplicon of the expected band size was observed. 
Table 6. Primers used in PCR based replicon typing of donor and transconjugant plasmids.

\begin{tabular}{|c|c|c|c|c|}
\hline Primer Panel/Target & Direction & Primer Sequence & Annealing Temp $\left({ }^{\circ} \mathrm{C}\right)$ & $\begin{array}{l}\text { Amplicon } \\
\text { Size (bp) }\end{array}$ \\
\hline \multicolumn{5}{|l|}{ Panel 1} \\
\hline \multirow{2}{*}{$\mathrm{B} / \mathrm{O}$} & $\mathrm{F}$ & $5^{\prime}$-gcggtccggaaagccagaaaac- $3^{\prime}$ & 60 & 159 \\
\hline & $\mathrm{R}$ & $5^{\prime}$-tctgcgttccgccaagttcga-3' & & \\
\hline \multirow[t]{2}{*}{ FIC } & $\mathrm{F}$ & $5^{\prime}$-gtgaactggcagatgaggaagg- $3^{\prime}$ & 60 & 262 \\
\hline & $\mathrm{R}$ & $5^{\prime}$-ttctcctcgtcgccaaactagat- $3^{\prime}$ & & \\
\hline \multirow[t]{2}{*}{$\mathrm{A} / \mathrm{C}$} & $\mathrm{F}$ & $5^{\prime}$-gagaaccaaagacaaagacctgga $3^{\prime}$ & 60 & 465 \\
\hline & $\mathrm{R}$ & $5^{\prime}$-acgacaaacctgaattgcctcctt- $3^{\prime}$ & & \\
\hline \multirow[t]{2}{*}{$\mathrm{P}$} & $\mathrm{F}$ & $5^{\prime}$ ctatggccetgcaaacgcgccagaaa $3^{\prime}$ & 60 & 534 \\
\hline & $\mathrm{R}$ & $5^{\prime}$-tcacgcgccagggcgcagcc- $3^{\prime}$ & & \\
\hline \multirow[t]{2}{*}{$\mathrm{T}$} & $\mathrm{F}$ & $5^{\prime}$-ttggcctgtttgtgcctaaaccat- $3^{\prime}$ & 60 & 750 \\
\hline & $\mathrm{R}$ & $5^{\prime}$-cgttgattacacttagctttggac- $3^{\prime}$ & & \\
\hline \multicolumn{5}{|l|}{ Panel 2} \\
\hline \multirow[t]{2}{*}{$\mathrm{K} / \mathrm{B}$} & $\mathrm{F}$ & $5^{\prime}$-gcggtccggaaagccagaaaac-3' & 60 & 160 \\
\hline & $\mathrm{R}$ & $5^{\prime}$-tctttcacgagcccgccaaa-3 & & \\
\hline \multirow[t]{2}{*}{$\mathrm{W}$} & $\mathrm{F}$ & $5^{\prime}$-cctaagaacaacaaagcccccg- $3^{\prime}$ & 60 & 242 \\
\hline & $\mathrm{R}$ & $5^{\prime}$-ggtgcgcggcatagaaccgt- $3^{\prime}$ & & \\
\hline \multirow[t]{2}{*}{$\mathrm{FII}_{\mathrm{S}}$} & $\mathrm{F}$ & $5^{\prime}$-ctgtcgtaagctgatggc- $3^{\prime}$ & 60 & 270 \\
\hline & $\mathrm{R}$ & $5^{\prime}$-ctctgccacaaacttcagc- $3^{\prime}$ & & \\
\hline \multirow[t]{2}{*}{ FIA } & $\mathrm{F}$ & $5^{\prime}$-ccatgctggttctagagaaggtg- $3^{\prime}$ & 60 & 462 \\
\hline & $\mathrm{R}$ & $5^{\prime}$-gtatatccttactggcttccgcag-3' & & \\
\hline \multirow[t]{2}{*}{ FIB } & $\mathrm{F}$ & $5^{\prime}$-ggagttctgacacacgattttctg- $3^{\prime}$ & 60 & 702 \\
\hline & & $5^{\prime}$-ctcccgtcgcttcagggcatt-3' & & \\
\hline \multirow[t]{2}{*}{ Y } & $\mathrm{F}$ & $5^{\prime}$-aattcaaacaacactgtgcagcctg-3' & 60 & 765 \\
\hline & $\mathrm{R}$ & $5^{\prime}$-gcgagaatggacgattacaaaacttt- $3^{\prime}$ & & \\
\hline \multicolumn{5}{|l|}{ Panel 3} \\
\hline \multirow[t]{2}{*}{ I1 } & $\mathrm{F}$ & $5^{\prime}$-cgaaagccggacggcagaa- $3^{\prime}$ & 60 & 139 \\
\hline & $\mathrm{R}$ & $5^{\prime}$-tcgtcgttccgccaagttcgt- $3^{\prime}$ & & \\
\hline \multirow[t]{2}{*}{$\mathrm{F}_{\text {repB }}$} & $\mathrm{F}$ & $5^{\prime}$-tgatcgtttaaggaattttg-3' & 60 & 270 \\
\hline & $\mathrm{R}$ & $5^{\prime}$-gaagatcagtcacaccatcc- $3^{\prime}$ & & \\
\hline \multirow[t]{2}{*}{$x$} & $\mathrm{~F}$ & $5^{\prime}$-aaccttagaggctatttaagttgctgat- $3^{\prime}$ & 60 & 376 \\
\hline & $\mathrm{R}$ & $5^{\prime}$-tgagagtcaatttttatctcatgttttagc $3^{\prime}$ & & \\
\hline \multirow[t]{2}{*}{ HI1 } & $\mathrm{F}$ & $5^{\prime}$-ggagcgatggattacttcagtac- $3^{\prime}$ & 60 & 471 \\
\hline & $\mathrm{R}$ & $5^{\prime}$-tgccgtttcacctcgtgagta- $3^{\prime}$ & & \\
\hline \multirow[t]{2}{*}{$\mathrm{N}$} & $\mathrm{F}$ & $5^{\prime}$-gtctaacgagcttaccgaag- $3^{\prime}$ & 60 & 559 \\
\hline & $\mathrm{R}$ & $5^{\prime}$-gtttcaactctgccaagttc- $3^{\prime}$ & & \\
\hline \multirow[t]{2}{*}{ HI2 } & $\mathrm{F}$ & $5^{\prime}$-tttctcctgagtcacctgttaacac- $3^{\prime}$ & 60 & 644 \\
\hline & $\mathrm{R}$ & $5^{\prime}$-ggctcactaccgttgtcatcct- $3^{\prime}$ & & \\
\hline \multirow[t]{2}{*}{$\mathrm{L} / \mathrm{M}$} & $\mathrm{F}$ & $5^{\prime}$-ggatgaaaactatcagcatctgaag- $3^{\prime}$ & 60 & 785 \\
\hline & $\mathrm{R}$ & $5^{\prime}$-ctgcaggggcgattctttagg- $3^{\prime}$ & & \\
\hline
\end{tabular}

\section{Conclusions}

Majority of plasmids carrying $b$ bla $_{\mathrm{CTX}-\mathrm{M}-15}$ were conjugatively transferred by IncF plasmids along with non-beta lactam resistance. The heterogeneous nature of these plasmids continuously maintains and reserves the $b l a_{\mathrm{CTX}-\mathrm{M}-15}$ gene in these settings. The $100 \%$ transfer efficiency among E. coli of animal origin is of concern since the networked interaction of animals with human and their environment continuously exchange and reserve resistance determinants in this interface. Therefore, there is a need for more research to understand the interaction and spread of mobile elements circulating in animals, One Health approach is to be intensified to further address AMR as a public health threat.

Author Contributions: Conceptualisation, C.A.M. and S.E.M.; Formal analysis, S.E.M.; Funding acquisition, C.A.M.; Investigation, C.A.M. and G.S.; Supervision, G.S. and S.E.M.; Writing-original draft, C.A.M.; Writing-review and editing, G.S. and S.E.M. All authors have read and agreed to the published version of the manuscript. 
Funding: This research was funded by the Centre for Research, Agricultural advancement, Teaching Excellence and Sustainability in Food and Nutritional Security (CREATES) of the Nelson Mandela African Institution of Science and Technology (NM-AIST). The APC was funded by Catholic University of Health and Allied Sciences (CUHAS).

Data Availability Statement: All data supporting presented results is available in this article.

Acknowledgments: The authors acknowledge the technical support provided by the department of Molecular biology at Nelson Mandela African Institution of Science and Technology. Specifically, we thank Emmanuel and Beatus Lyimo for providing necessary technical assistance.

Conflicts of Interest: The authors declare no conflict of interest. The funders had no role in the design of the study; in the collection, analyses or interpretation of data; in the writing of the manuscript or in the decision to publish the results.

$\begin{array}{ll}\text { Abbreviations } \\ \text { AMR } & \begin{array}{l}\text { Antimicrobial resistance } \\ \text { CREATES }\end{array} \\ & \begin{array}{l}\text { Centre for Research, Agricultural advancement, Teaching Excellence and Sustainability } \\ \text { in Food and Nutritional Security }\end{array} \\ \text { CUHAS } & \text { Catholic University of Health and Allied Sciences } \\ \text { DNA } & \text { Deoxyribonucleic acid } \\ \text { EDTA } & \text { Ethylene Diaminetetracetic acid } \\ \text { ESBL } & \text { Extended spectrum beta-lactamase } \\ \text { GIT } & \text { Gastrointestinal tract } \\ \text { LB } & \text { Luria Bertani } \\ \text { MGE } & \text { Mobile genetic element } \\ \text { NaCl } & \text { Sodium Chloride } \\ \text { NaN } & \text { Sodium azide } \\ \text { PCR } & \text { Polymerase chain reaction } \\ \text { TAE } & \text { Tris acetate EDTA }\end{array}$

\section{References}

1. Barlow, M. What antimicrobial resistance has taught us about horizontal gene transfer. Horiz. Gene Transf. 2009, 397-411. [CrossRef]

2. Bonnet, R. Growing group of extended-spectrum $\beta$-lactamases: The CTX-M enzymes. Antimicrob. Agents Chemother. 2004, 48, 1-14. [CrossRef]

3. Lahlaoui, H.; Khalifa, A.B.H.; Moussa, M.B. Epidemiology of Enterobacteriaceae producing CTX-M type extended spectrum $\beta$-lactamase (ESBL). Med. Et Mal. Infect. 2014, 44, 400-404. [CrossRef] [PubMed]

4. Hirai, I.; Fukui, N.; Taguchi, M.; Yamauchi, K.; Nakamura, T.; Okano, S.; Yamamoto, Y. Detection of chromosomal blaCTX-M-15 in Escherichia coli O25b-B2-ST131 isolates from the Kinki region of Japan. Int. J. Antimicrob. Agents 2013, 42, 500-506. [CrossRef] [PubMed]

5. Coque, T.M.; Novais, Â.; Carattoli, A.; Poirel, L.; Peixe, L.; Baquero, F.; Cantón, R.; Nordmann, P. Dissemination of clonally related Escherichia coli strains expressing extended-spectrum $\beta$-lactamase CTX-M-15. Emerg. Infect. Dis. 2008, 14, 195. [CrossRef] [PubMed]

6. Martin, J.F.; Liras, P. Organization and expression of genes involved in the biosynthesis of antibiotics and other secondary metabolites. Annu. Rev. Microbiol. 1989, 43, 173-206. [CrossRef] [PubMed]

7. Allen, H.K.; Moe, L.A.; Rodbumrer, J.; Gaarder, A.; Handelsman, J. Functional metagenomics reveals diverse $\beta$-lactamases in a remote Alaskan soil. ISME J. 2009, 3, 243-251. [CrossRef]

8. Paterson, D.L.; Bonomo, R.A. Extended-spectrum $\beta$-lactamases: A clinical update. Clin. Microbiol. Rev. 2005, 18, 657-686. [CrossRef]

9. Cantón, R.; González-Alba, J.M.; Galán, J.C. CTX-M enzymes: Origin and diffusion. Front. Microbiol. 2012, 3, 110. [CrossRef]

10. Naseer, U.; Sundsfjord, A. The CTX-M conundrum: Dissemination of plasmids and Escherichia coli clones. Microb. Drug Resist. 2011, 17, 83-97. [CrossRef]

11. Vrancianu, C.O.; Popa, L.I.; Bleotu, C.; Chifiriuc, M.C. Targeting plasmids to limit acquisition and transmission of antimicrobial resistance. Front. Microbiol. 2020, 11, 761. [CrossRef] [PubMed]

12. Lopatkin, A.J.; Meredith, H.R.; Srimani, J.K.; Pfeiffer, C.; Durrett, R.; You, L. Persistence and reversal of plasmid-mediated antibiotic resistance. Nat. Commun. 2017, 8, 1689. [CrossRef] [PubMed]

13. Levin, B.R.; Rozen, D.E. Non-inherited antibiotic resistance. Nat. Rev. Microbiol. 2006, 4, 556-562. [CrossRef] [PubMed]

14. Benz, F.; Huisman, J.S.; Bakkeren, E.; Herter, J.A.; Stadler, T.; Ackermann, M.; Diard, M.; Egli, A.; Hall, A.R.; Hardt, W.-D. Plasmidand strain-specific factors drive variation in ESBL-plasmid spread in vitro and in vivo. ISME J. 2021, 15, 862-878. [CrossRef] 
15. Yang, Q.E.; Agouri, S.R.; Tyrrell, J.M.; Walsh, T.R. Heavy metal resistance genes are associated with blaNDM-1-and blaCTX-M-15carrying Enterobacteriaceae. Antimicrob. Agents Chemother. 2018, 62, e02642-17. [CrossRef] [PubMed]

16. Hernández-Ramírez, K.C.; Reyes-Gallegos, R.I.; Chávez-Jacobo, V.M.; Díaz-Magaña, A.; Meza-Carmen, V.; Ramírez-Díaz, M. A plasmid-encoded mobile genetic element from Pseudomonas aeruginosa that confers heavy metal resistance and virulence. Plasmid 2018, 98, 15-21. [CrossRef]

17. Nicolas-Chanoine, M.-H.; Blanco, J.; Leflon-Guibout, V.; Demarty, R.; Alonso, M.P.; Caniça, M.M.; Park, Y.-J.; Lavigne, J.-P.; Pitout, J.; Johnson, J.R. Intercontinental emergence of Escherichia coli clone O25: H4-ST131 producing CTX-M-15. J. Antimicrob. Chemother. 2008, 61, 273-281. [CrossRef]

18. Mshana, S.E.; Hain, T.; Domann, E.; Lyamuya, E.F.; Chakraborty, T.; Imirzalioglu, C. Predominance of Klebsiella pneumoniae ST14 carrying CTX-M-15 causing neonatal sepsis in Tanzania. BMC Infect. Dis. 2013, 13, 466. [CrossRef]

19. Mshana, S.E.; Falgenhauer, L.; Mirambo, M.M.; Mushi, M.F.; Moremi, N.; Julius, R.; Seni, J.; Imirzalioglu, C.; Matee, M.; Chakraborty, T. Predictors of bl a CTX-M-15 in varieties of Escherichia coli genotypes from humans in community settings in Mwanza, Tanzania. BMC Infect. Dis. 2016, 16, 187. [CrossRef]

20. Mshana, S.; Imirzalioglu, C.; Hain, T.; Domann, E.; Lyamuya, E.F.; Chakraborty, T. Multiple ST clonal complexes, with a predominance of ST131, of Escherichia coli harbouring blaCTX-M-15 in a tertiary hospital in Tanzania. Clin. Microbiol. Infect. 2011, 17, 1279-1282. [CrossRef]

21. Seni, J.; Falgenhauer, L.; Simeo, N.; Mirambo, M.M.; Imirzalioglu, C.; Matee, M.; Rweyemamu, M.; Chakraborty, T.; Mshana, S.E. Multiple ESBL-producing Escherichia coli sequence types carrying quinolone and aminoglycoside resistance genes circulating in companion and domestic farm animals in Mwanza, Tanzania, harbor commonly occurring plasmids. Front. Microbiol. 2016, 7, 142. [CrossRef]

22. Moremi, N.; Manda, E.V.; Falgenhauer, L.; Ghosh, H.; Imirzalioglu, C.; Matee, M.; Chakraborty, T.; Mshana, S.E. Predominance of CTX-M-15 among ESBL producers from environment and fish gut from the shores of Lake Victoria in Mwanza, Tanzania. Front. Microbiol. 2016, 7, 1862. [CrossRef]

23. Mshana, S.E.; Gerwing, L.; Minde, M.; Hain, T.; Domann, E.; Lyamuya, E.; Chakraborty, T.; Imirzalioglu, C. Outbreak of a novel Enterobacter sp. carrying blaCTX-M-15 in a neonatal unit of a tertiary care hospital in Tanzania. Int. J. Antimicrob. Agents 2011, 38, 265-269. [CrossRef]

24. Seni, J.; Falgenhauer, L.; Simeo, N.; Mirambo, M.; Imirzalioglu, C.; Matee, M.; Rweyemamu, M.; Chakraborty, T.; Mshana, S.E. Preliminary insights into the occurrence of similar clones of extended-spectrum beta-lactamase-producing bacteria in humans, animals and the environment in Tanzania: A systematic review and meta-analysis between 2005 and 2016. Zoonoses Public Health 2018, 65, 1-10. [CrossRef]

25. Hosuru Subramanya, S.; Bairy, I.; Nayak, N.; Amberpet, R.; Padukone, S.; Metok, Y.; Bhatta, D.R.; Sathian, B. Detection and characterization of ESBL-producing Enterobacteriaceae from the gut of healthy chickens, Gallus gallus domesticus in rural Nepal: Dominance of CTX-M-15-non-ST131 Escherichia coli clones. PLoS ONE 2020, 15, e0227725. [CrossRef]

26. Mshana, S.E.; Kamugisha, E.; Mirambo, M.; Chakraborty, T.; Lyamuya, E. Prevalence of multiresistant gram-negative organisms in a tertiary hospital in Mwanza, Tanzania. BMC Res. Notes 2009, 2, 49. [CrossRef]

27. Obeng-Nkrumah, N.; Labi, A.-K.; Blankson, H.; Awuah-Mensah, G.; Oduro-Mensah, D.; Anum, J.; Teye, J.; Kwashie, S.D.; Bako, E.; Ayeh-Kumi, P.F. Household cockroaches carry CTX-M-15-, OXA-48-and NDM-1-producing enterobacteria, and share beta-lactam resistance determinants with humans. BMC Microbiol. 2019, 19, 272. [CrossRef]

28. Lyimo, B.; Buza, J.; Subbiah, M.; Temba, S.; Kipasika, H.; Smith, W.; Call, D.R. IncF plasmids are commonly carried by antibiotic resistant Escherichia coli isolated from drinking water sources in northern Tanzania. Int. J. Microbiol. 2016, 2016, 3103672. [CrossRef] [PubMed]

29. Gekenidis, M.-T.; Rigotti, S.; Hummerjohann, J.; Walsh, F.; Drissner, D. Long-Term Persistence of blaCTX-M-15 in Soil and Lettuce after Introducing Extended-Spectrum $\beta$-Lactamase (ESBL)-Producing Escherichia coli via Manure or Water. Microorganisms 2020, 8, 1646. [CrossRef]

30. Zurfluh, K.; Glier, M.; Hächler, H.; Stephan, R. Replicon typing of plasmids carrying blaCTX-M-15 among Enterobacteriaceae isolated at the environment, livestock and human interface. Sci. Total Environ. 2015, 521, 75-78. [CrossRef] [PubMed]

31. San Millan, A.; Peña-Miller, R.; Toll-Riera, M.; Halbert, Z.V.; McLean, A.R.; Cooper, B.S.; MacLean, R.C. Positive selection and compensatory adaptation interact to stabilize non-transmissible plasmids. Nat. Commun. 2014, 5, 5208. [CrossRef]

32. Dionisio, F.; Conceicao, I.C.; Marques, A.C.R.; Fernandes, L.; Gordo, I. The evolution of a conjugative plasmid and its ability to increase bacterial fitness. Biol. Lett. 2005, 1, 250-252. [CrossRef]

33. Ragupathi, N.K.D.; Sethuvel, D.P.M.; Gajendran, R.; Anandan, S.; Walia, K.; Veeraraghavan, B. Horizontal transfer of antimicrobial resistance determinants among enteric pathogens through bacterial conjugation. Curr. Microbiol. 2019, 76, 666-672. [CrossRef] [PubMed]

34. Rozwandowicz, M.; Brouwer, M.S.M.; Fischer, J.; Wagenaar, J.A.; Gonzalez-Zorn, B.; Guerra, B.; Mevius, D.J.; Hordijk, J. Plasmids carrying antimicrobial resistance genes in Enterobacteriaceae. J. Antimicrob. Chemother. 2018, 73, 1121-1137. [CrossRef]

35. Yousfi, M.; Mairi, A.; Touati, A.; Hassissene, L.; Brasme, L.; Guillard, T.; De, C.C. Extended spectrum $\beta$-lactamase and plasmid mediated quinolone resistance in Escherichia coli fecal isolates from healthy companion animals in Algeria. J. Infect. Chemother. 2016, 22, 431-435. [CrossRef] [PubMed] 
36. Rafaï, C.; Frank, T.; Manirakiza, A.; Gaudeuille, A.; Mbecko, J.-R.; Nghario, L.; Serdouma, E.; Tekpa, B.; Garin, B.; Breurec, S. Dissemination of IncF-type plasmids in multiresistant CTX-M-15-producing Enterobacteriaceae isolates from surgical-site infections in Bangui, Central African Republic. BMC Microbiol. 2015, 15, 15. [CrossRef]

37. Kiiru, J.; Butaye, P.; Goddeeris, B.M.; Kariuki, S. Analysis for prevalence and physical linkages amongst integrons, ISE cp 1, IS CR 1, Tn 21 and Tn 7 encountered in Escherichia coli strains from hospitalized and non-hospitalized patients in Kenya during a 19-year period (1992-2011). BMC Microbiol. 2013, 13, 109. [CrossRef]

38. Mshana, S.E.; Imirzalioglu, C.; Hossain, H.; Hain, T.; Domann, E. Chakraborty, T. Conjugative IncFI plasmids carrying CTX-M-15 among Escherichia coli ESBL producing isolates at a University hospital in Germany. BMC Infect. Dis. 2009, 9, 97. [CrossRef]

39. Maherault, A.-C.; Kemble, H.; Magnan, M.; Gachet, B.; Roche, D.; Le Nagard, H.; Tenaillon, O.; Denamur, E.; Branger, C.; Landraud, L. Advantage of the F2: A1: B-IncF pandemic plasmid over IncC plasmids in in vitro acquisition and evolution of blaCTX-M gene-bearing plasmids in Escherichia coli. Antimicrob. Agents Chemother. 2019, 63, e01130-19. [CrossRef] [PubMed]

40. Lee, M.Y.; Ko, K.S.; Kang, C.-I.; Chung, D.R.; Peck, K.R.; Song, J.-H. High prevalence of CTX-M-15-producing Klebsiella pneumoniae isolates in Asian countries: Diverse clones and clonal dissemination. Int. J. Antimicrob. Agents 2011, 38, 160-163. [CrossRef]

41. Dionisio, F.; Zilhão, R.; Gama, J.A. Interactions between plasmids and other mobile genetic elements affect their transmission and persistence. Plasmid 2019, 102, 29-36. [CrossRef]

42. Johnson, T.J.; Wannemuehler, Y.M.; Johnson, S.J.; Logue, C.M.; White, D.G.; Doetkott, C.; Nolan, L.K. Plasmid replicon typing of commensal and pathogenic Escherichia coli isolates. Appl. Environ. Microbiol. 2007, 73, 1976-1983. [CrossRef]

43. Clinical Laboratory Standards Institute. Performance Standards for Antimicrobial Susceptibility Testing, 28th ed.; CLSI Standard M100: Wayne, PA, USA, 2018.

44. Jacoby, G.A.; Han, P. Detection of extended-spectrum beta-lactamases in clinical isolates of Klebsiella pneumoniae and Escherichia coli. J. Clin. Microbiol. 1996, 34, 908-911. [CrossRef]

45. Casquet, J.; Thebaud, C.; Gillespie, R.G. Chelex without boiling, a rapid and easy technique to obtain stable amplifiable DNA from small amounts of ethanol-stored spiders. Mol. Ecol. Resour. 2012, 12, 136-141. [CrossRef]

46. Carattoli, A.; Bertini, A.; Villa, L.; Falbo, V.; Hopkins, K.; Threlfall, E. Identification of plasmids by PCR-based replicon typing. J. Microbiol. Methods 2005, 63, 219-228. [CrossRef] 